\title{
SEJARAH PERKEMBANGAN ILMU TAFSIR
}

\author{
Syarif Idris \\ Dosen Syari'ah Universitas Muhammadiyah Kupang \\ Email: uwaissyarif2018@gmail.com
}

\begin{abstract}
Abstrak
Al-Qur'an merupakan mukjizat terbesar Islam yang abadi sekaligus menjadi sumber ilmu yang tidak pernah bertentangan dengan kemajuan ilmu pengetahuan manusia, namun semakin tampak validitas kemukjizatan. Allah swt menurunkannya kepada Nabi Muhammad saw, demi membebaskan manusia dari berbagai kegelapan hidup menuju cahaya Ilahi, dan membimbing mereka ke jalan yang lurus. Rasulullah saw menyampaikan kepada para sahabatnya sebagai penduduk asli Arab yang sudah tentu dapat memahami tabiat mereka. Para sahabat sangat bersemangat untuk mendapatkan pengajaran Al-Qur'an dari Rasulullah saw. Mereka ingin menghafal Al-Qur'an dan memahaminya. Selain itu Al-Qur'an telah menyatakan dirinya sebagai kitab petunjuk yang dapat menuntun manusia menuju ke jalan yang benar. Selain itu, ia juga berfungsi sebagai pemberi penjelasan terhadap segala sesuatu dan pembeda antara kebenaran dan kebatilan. Untuk mengungkap petunjuk dan penjelasan dari Al-Qur'an, telah dilakukan berbagai upaya oleh sejumlah pakar dan Ulama yang berkompeten untuk melakukan penafsiran terhadap Al-Qur'an, sejak masa awalnya hingga sekarang. Keindahan bahasa Al-Qur'an, kedalaman maknanya, serta keragaman temanya, membuat pesan yang terkandung tidak pernah berkurang, apa lagi habis, meskipun telah dikaji dari berbagai aspeknya. Keagungan dan keajaiban selalu muncul dengan perkembangan akal manusia dari masa ke masa. Kandungannya seakan tidak lekang disengat panas dan dan tidak lapuk diterpa hujan. Karena itu, upaya menghadirkan pesan-pesan AlQur'an merupakan proses yang tidak pernah berakhir selama manusia hadir di muka bumi. Dari sinilah muncul sejumlah karya tafsir dalam berbagai corak dan metodeloginya seperti, tafsir Ibnu Abbas, At-Thabari, Ibnu Kasir, Asy Syaukani dan lain-lain.
\end{abstract}

Kata Kunci: Al-Qur'an, Tafsir, Hadits

\section{Pendahuluan}

andangan aqidah dalam Islam bahwa al-Qur'an shalihun li kulli zaman wa
makan merupakan konsep berkeyakinan umar Islam bahwa doktrin kebenaran
al-Qur'an bersifat pasti. Akibatnya muncul respon reaktif terhadap setiap perkembangan situasi yang terjadi dalam perjalanan sejarah peradaban manusia sekarang. Misalnya dengan mengatakan bahwa semua ilmu pengetahuan yang ada sekarang ini dan pada masa yang akan datang sudah ada semuanya dalam al-Qur'an. Seperti yang diungkapkan oleh al-Ghazali dalam Jawahir al-Qur'an, bahwa untuk 
memahami Al-Qur'an tidak semua manusia bisa memahamakan Al-Qur'an berdasarkan akal pikiran mereka, kecuali orang-orang yang mempunyai kewenangan keilmuan yang khusus. Dalam hal ini para sahabat dan ulamalah yang mempunyai kompetensi dalam ilmu tafsir. Memahami Al-Qur'an harus berdasarkan Ilmu tafsir sebagaimana yang dilakukan oleh Nabi Muhammad SAW. Karena tafsir yang dilakukan oleh Nabi Muhammad SAW Merupakan tafsir yang terbaik yang sesuai dengan kebenaran yang diturunkan Allah kepada Nabi Muhammad SAW. Setelah Rasulullah SAW tiada sebagai tafsir yang terbaik dilanjutkan oleh para sahabat. Tafsir para sahabat merupakan tafsir yang terbaik setelah Rasulullah SAW karena, para sahabat merupakan murid yang langsung berguru kepada Rasulullah SAW.

Sebagian ulama menganggap respon di atas tentunya tidak produktif. Sebab jika ada penemuan baru berdasarkan metodologi ilmu pengetahuan kontemporer yang kontradiktif dengan al-Qur'an muncul respon defensif yang seringkali menempatkan informasi-informasi dalam teks al-Qur'an pada ukuran mistik. Ada semacam pemaksaan teologis dalam rangka menyelamatkan kebenaran al-Qur'an tersebut. Padahal upaya ini justru akan memposisikan al-Qur'an secara sempit untuk dipahami. Pemahaman al-Qur'an hanya terbatas pada ruang dan waktu ketika al-Qur'an itu turun, atau paling tidak sampai pada waktu ulama-ulama dulu saja. Oleh karena itu diperlukan upaya yang lebih produktif dalam rangka mempertahankan pandangan teologis di atas. Salah satunya adalah mengembangkan tafsir kontemporer dengan menggunakan metodologi baru yang sesuai dengan perkembangan situasi sosial, budaya, ekonomi, ilmu pengetahuan dan perkembangan peradaban manusia. Persoalannya adalah bagaimana merumuskan sebuah metode tafsir yang mampu menjadi alat untuk menafsirkan al-Qur'an secara baik, dialektis, reformatif, komunikatif serta mampu menjawab perubahan dan perkembangan problem kontemporer yang dihadapi umat manusia sekarang ini.

\section{Mendeskripsikan Pengertian Tafsir}

Tafsir secara bahasa mengikuti wazan "taf'il," yang artinya menjelaskan, menyingkap dan menerangkan makna-makna rasional. ${ }^{1}$ Sebagian Ulama berpendapat, kata Tafsir adalah kata kerja yang terbalik, berasal dari kata "safara" yang juga memiliki makna menyingkap ${ }^{2}$. Ilmu tafsir merupakan ilmu yang paling mulia dan paling tinggi kedudukannya, karena pembahasannya berkaitan dengan Kalamullah yang merupakan petunjuk dan pembeda dari yang haq dan bathil. Ilmu tafsir telah

\footnotetext{
2013), 407

${ }^{1}$ Syaikh Manna Al-Qattan, Pengantar Studi Ilmu Qur'an, (Jakarta: Pustaka Al-Kautsar,

${ }^{2}$ Ibid., 407
} 
dikenal sejak zaman Rasulullah dan berkembang hingga di zaman modern sekarang ini. $^{3}$

Ilmu tafsir adalah ilmu yang pokok dalam Al-Qur'an karena ilmu ini menjelaskan kalimat, huruf dalam Al-Qur'an. Memahamkan Al-Qur'an harus berdasarkan ilmu tafsir yang diberi otoritas khusus oleh para Ulama. Tidak semua orang bebas menafsirkan Al-Qur'an kecuali para mufassiriin yang mempunyai kewenangan dalam menafsirkan Al-Qur'an. Alquran salah satu dari sejumlah kecil kitab suci yang telah memberikan pengaruh begitu luas dan mendalam dalam jiwa dan tindakan manusia. Bagi kaum muslimin Alquran bukan saja sebagai kitab suci melainkan juga petunjuk yang menjadi pedoman sikap dan tindakan mereka dalam memainkan peran sebagai manusia di muka bumi. Ibarat katalog sebuah produk barang, Alquran adalah petunjuk bagi pengelola alam ini sehinga berfungsi dengan baik. Maka baik buruknya managemen dan pendayagunaan alam sangat tergantung kepada tinggi rendahnya intensitas komitmen manusia terhadap petunjuk Alquran. Karena itu, tafsir dan yang berkaitan dengannya telah mendapat perhatian besar sejak masa awal perkembangan Islam sampai masa kini hingga masa mendatang mengingat posisi sentral yang dimilikinya sebagai petunjuk. ${ }^{4}$

Pada saat al-Quran diturunkan, Rasul SAW, berfungsi sebagai pemberi peringatan, menjelaskan kepada sahabat-sahabatnya tentang arti dan kandungan alQuran, khususnya menyangkut ayat-ayat yang tidak dimengerti atau samar artinya. Keadaan ini berlangsung sampai dengan wafatnya Rasul SAW, walaupun harus diakui bahwa penjelasan tersebut tidak semua kita ketahui akibat tidak sampainya riwayat-riwayat yang berkaitan dengannya. Kalau pada masa Rasul SAW, para sahabat menanyakan persoalan-persoalan yang tidak jelas kepada beliau, maka setelah wafatnya, mereka terpaksa melakukan ijtihad, seperti 'Ali bin Abi Thalib, Ibnu 'Abbas, Ubay bin Ka'ab, dan Ibnu Mas'ud. ${ }^{5}$

\section{Rasulullah Penafsir Pertama Al-Qur'an}

Perlu diketahui bahwa Rasulullah SAW telah menjelaskan isi kandungan AlQur'an kepada para sahabat. Beliau memaparkan setiap ayatnya sebagaimana dijelaskan oleh Allah SWT dalam surat An-Nahl/16 ayat 44, yang artinya "(Mereka Kami utus) dengan membawa keterangan-keterangan (mukzizat) dan kitab-kitab. Dan kami turunkan az-Zikr (Al-Qur'an) kepadamu agar engkau menerangkan kepada manusia apa yang telah diturunkan kepada mereka dan agar mereka

\footnotetext{
${ }^{3}$ Ahmad, Syazdali, Ahmad Rafi'i. Ulumul Quran . (Bandung : CV. Pustaka Setia, 1997), . 24.

${ }^{4}$ Ali Hasan Al-Aridl. Sejarah dan Metodologi Tafsir (terj.). (Jakarta: Raja Grafindo Persada, 1994), 124.

${ }^{5}$ Ibid., 126.
} 
memikirkan". Meski demikian bangsa Arab pada masa-masa awal turunnya al-Quran telah mempunyai kemampuan untuk memahami maksud dan tujuan dalam ayat-ayat al-Qsuran. Mereka tidak perlu menanyakan arti dan makna al-Quran maupun tafsirnya kepada Nabi SAW. Mereka sudah cukup dengan kemampuan bahasa yang mereka miliki dan mampu mengingat aspek-aspek sastra arab sudah mereka kenal sebelum mereka menerima al-Quran. ${ }^{6}$ Dalam suasana seperti ini, belum dirasakan perlunya ilmu tafsir. Demikian pula untuk membentuk kelompok-kelompok studi, kecuali untuk sebagian ayat yang memang dirasa kompleks bagi para sahabat. ${ }^{7}$ Untuk masalah seperti ini mereka akan menanyakan kepada Nabi. Pada masanya, dalam menafsirkan al-Quran para sahabat bergantung kepada lima hal, yaitu:

\section{Al-Qur'an}

Metode tafsir yang terbaik adalah metode tafsir Al-Qur'an dengan Al-Qur'an. Keterangan yang disebutkan secara umum pada satu ayat, dijelaskan secara detail pada ayat yang lain; dan pesan yang disampaikan secara singkat pada satu ayat, diuraikan dengan panjang lebar pada ayat yang lain. ${ }^{8}$ Tafsir Al-Qur'an dengan AlQur'an pun banyak terdapat dalam kisah-kisah para Nabi yang dipaparkan secara garis besar, seperti dalam surat Al-Haqqah ayat 5, yang artinya "Maka adapun kaum tsamud, mereka telah dibinasakan dengan suara yang sangat keras, " kata thaghiyah pada ayat ini disebutkan secara umum, lalu dijelaskan pada tempat yang lain, seperti firman Allah "Kami kirimkan atas mereka suatu suara yang keras mengguntur”, (Alqomar 31), sehingga thaghiyah pada surat Al-Haqqah ayat 5 ditafsirkan dengan suara keras yang mengguntur.

Diharamkan bagimu untuk memakan bangkai, darah, daging babi, hewan yang disembelih atas nama selain Allah, yang tercekik, dipukul, jatuh, yang ditanduk, dan yang diterkam binatang buas kecuali yang kalian sempat menyembelihnya, dan (diharamkan bagimu) yang disembelih untuk berhala, dan (diharamkan juga) mengundi nasib dengan anak panah. Syeikh Islam Ibnu Taimiyah mengatakan metode yang paling shohih dalam menafsirkan Al-Qur'an yaitu, tafsir Al-Qur'an dengan AlQur'an. Ibnu Taimiyah disini mengemukakan metode tafsir yang paling bagus dan paling utama yaitu menafsirkan ayat dengan ayat lain. ${ }^{9}$

${ }^{6}$ Abdul Hayy Al-Farmawi. Metode Tafsir Maudhu'i dan Penerapannya. (Bandung: Pustaka Setia, 2002), 239.

${ }^{7}$ Ibid., 240.

${ }^{8}$ Syaekh Muhammad Shalih Al-Utsaimin, Sejarah Pengantar Ilmu Tafsir Ibnu Taimiyah, Penerj. Sholihin, (Jakarta: Pustaka Al-Kautsar, 2014), 342

${ }^{9}$ Ibid, 345 . 


\section{Hadits Nabi Muhammad SAW}

Allah SWT menjelaskan kepada Rasulullah SAW dengan cara memberi keterangan yang jelas atau memberikan pemahaman makna, sehingga pesan dan kandungan Al-Qur'an dapat diketahui. Selanjutnya, beliau menjelaskan pesan tersebut kepada para sahabat, baik dengan perkataan maupun dengan perbuatan. Rasulullah SAW menjelaskan tentang al-Quran, ketika sahabat merasa kesulitan dalam memahami sebuah ayat maka mereka kembali bertanya kepada Nabi SAW. ${ }^{10}$ Berikut ini adalah contoh pertanyaan yang dilakukan sahabat dan jawaban yang diberikan Nabi SAW kepada mereka: "Sahabat bertanya kepada Nabi SAW tentang makna المغضوب عليهم ولا الضـالين yang terdapat pada akhir surat al-Fatihah. Nabi

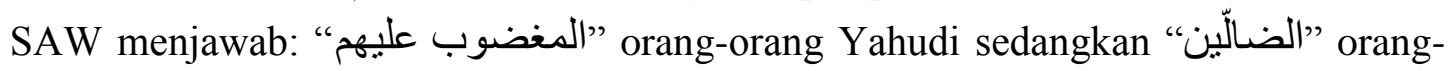
orang Nasrani". Jawaban Nabi SAW ini diriwayatkan oleh Ibn Hiban dan ia menshahihkannya. Sebagian ulama memberikan perhatian yang serius terhadap hadishadis yang berfungsi sebagai penafsir ayat-ayat al-Quran. Mereka menghimpunnya dalam model penafsiran dengan tafsir bi al-ma'tsur ${ }^{11}$. Asunnah juga disampaikan secara wahyu, seperti turunnya Al-Qur'an. Namun, membaca As-Sunnah tidak bernilai ibadah layaknya membaca Al-Qur'an. Dalam konteks inilah Imam Syafi'i dan para imam lainnya memiliki pendapat yang sama tentang fungsi As-Sunnah sebagai penafsir Al-Qur'an. ${ }^{12}$

\section{Ijtihad}

Kedua sumber penafsiran tersebut disepakati diterima oleh semua sahabat, tidak demikian dengan ijtihad. Para sahabat berbeda pendapat akan diterimanya tafsir dengan pedoman ijtihad ini. Sebagian mereka hanya berpedoman pada riwayat saja. Namun, sebagian dari mereka selain menggunakan riwayat, juga menggunakan ijtihad. Dalam buku Sejarah dan Pengantar Ilmu al-Quran, Hamka menjelaskan bahwa yang digunakan untuk berpegang dalam metode ini adalah kekuatan bahasa dan asbabunnuzul. ${ }^{13}$ Para sahabat yang tidak membenarkan tafsir dengan metode ijtihad ini adalah Abu Bakar dan Umar r.a. Sedangkan sahabat yang menafsirkan alQuran dengan metode ijtihad adalah Ibnu Mas'ud dan Ibnu Abbas. Namun dengan kepandaian yang diberikan Allah kepada Ibnu Abbas kemudian ia digelari dengan Tarjuman al-Qur'an.

${ }^{10}$ Abdul Hayy Al-Farmawi...,242.

${ }^{11}$ M. Hasbi Ash Shiddieqy. Sedjarah dan Pengantar Ilmu al-Quran/Tafsir. (Jakarta: Bulan Bintang, 1972), 201.

${ }^{12}$ Syaekh Muhammad Shalih Al-Utsaimin..., 343

${ }^{13}$ Abdul Hayy Al-Farmawi....,244. 
Meskipun para sahabat pada waktu itu sudah menggunakan metode ijtihad, tetapi mereka tidak sampai merumuskan kaidah-kaidah bahasa maupun nahwu. Secara akal sehat mereka masih memahami dengan baik citarasa bahasa Arab yang murni sebelum banyak berhubungan dengan bahasa lain. Mereka sudah memahami unsur-unsur balaghah seperti ijaz, ithnab, majaz, tasybih, dan lain-lain. Para mufassir di masa sahabat nabi saw, diantaranya yang paling masyhur ada sembilan yaitu: empat Khulafa', Ibnu Mas'ud, Ibnu Abbas, Zaid Ibnu Tsabit, Abu Musa al-Asy'ariy, dan 'Abdullah Ibn Zubair r.a. Pada masa Sahabat ini belum dilakukan pengumpulan terhadap tafsir al-Quran. Mereka tidak menulis tafsir, karena kondisi waktu itu tafsir merupakan bagian dari hadis. Sehingga dengan argmentasi takut bercampur dengan al-Quran, mereka tidak menulis tafsir. Dimulainya pengumpulan terjadi pada masa abad kedua, ketika waktu itu Umar ibn 'Abd al-'Aziz menjadi khalifah pada tahun 99 H. Waktu itu tafsir hanyalah salah satu bab dari kitab Hadis.

\section{Sahabat Nabi Muhammad SAW}

Dengan demikian apabila kami tidak menemukan penjelasan dalam Al-Qur'an dan As-Sunnah, maka kami merujuk kepada pendapat para sahabat, karena mereka lebih mengetahui hal itu ${ }^{14}$. Para sahabat menyaksikan turunnya Al-Qur'an dan berbagai kondisi khusus yang melatarbelakanginya. Disamping itu para sahabat memiliki pemahaman yang sempurna dan ilmu yang shohih, terlebih lagi para Ulama dan pembesar mereka seperti Abu Bakar, Umar bin Khatab, Utsman bin Affan dan Ali bin Abi Tahalib. Syeikh Al-Utsaimin menyatakan, apabila kami tidak menemukan penjelasan dalam Al-Qur'an dan As-Sunnah, kami merujuk kepada pernyataan sahabat. ${ }^{15}$ Pernyataan ini mengindikasikan anjuran safar untuk menuntut ilmu. Lewat pernyataan ini Ibn Mas'ud tidak bermaksud untuk memuji dan membanggakan diri sendiri. Tetapi, maksudnya memotifasi kita untuk mempelajari kitabullah dan menggali tafsir Al-Qur'an dari ahlinya. Bisa jadi Ibn Mas'ud ingin mengajarka kita semua tentang Al-Qur'an.

Para sahabat mempelajari wahyu langsung dari Rasulullah saw, mengkaji seluruh ayat, kemudian beramal sesuai petunjuk ayat tersebut. Disamping belajar mengamalkan suatu ayat, mereka juga menggali makna Al-Qur'an dari Rasulullah saw, sebagaimana keterangan Abdullah bin Hubaib As-Sulami. Ditemukan sejumlah tafsir dari beberapa orang sahabat. Mereka tidak menjelaskan bahwa tafsir tersebut dari bebrapa orang sahabat. Mereka tidak menjelaskan bahwa tafsir tersebut bersumber dari Rasulullah saw. Tafsir ini dikemukakan begitu saja seperti bersumber

\footnotetext{
${ }^{14}$ Syaekh Muhammad Shalih Al-Utsaimin...,365

${ }^{15} \mathrm{Ibid}, 369$
} 
dari pendapat mereka, padahal tafsir yang sama tidak dikemukakan berdasarkan rasio. Jadi, hukum tafsir ini adalah marfu' ${ }^{16}$

\section{Tafsir Pada Masa Tabi'in}

Apabila tidak menemukan tafsir dalam Al-Qur'an, As-Sunnah, dan juga pendapat sahabat, mayoritas ulama dalam kasusu ini merujuk kepada pendapat tabi'in, seperti Mujahidbin Jubair. Beliau alim dalam bidang tafsir, sebagaimana dikemukakan oleh Muhammad bin Ishaq. Ada beberapa lokasi yang oleh tabi'in dijadikan sebagai pusat perkembangan ilmu tafsir. Para tabi'in mendapatkan qaulqaul sahabat di tiga tempat yaitu Makkah, Madinah dan di Iraq. Skyeikh Islam Ibnu Taimiyyah mengatakan: "Orang-orang yang paling paham tentang tafsir adalah orang-orang Makkah, karena mereka adalah murid-murid Ibnu Abbas r.a. seperti Mujahid, 'Ikrimah, Jubair, Thawus, dan lain-lain. Begitu juga di Iraq ada muridmurid Ibnu Mas'ud. Sedangkan di Madinah di bidang tafsir seperti Zaid Ibnu Aslam. Sebagaimana para sahabat, tabi'in pun ada yang menerima tafsir dengan ijtihad ada pula yang menolaknya karena berbagai macam pandangan. Ada beberapa kelompok yang tidak membolehkan mengkritik orang yang membolehkan dengan beberapa hadis. Diantara tabi'in yang tidak menerima metode tafsir bi al-ijtihad adalah Sa'id Ibn al-Musayyab dan Ibnu Sirin. Diantara tabi'in yang membolehkan seperti Mujahid, 'Ikrimah dan sahabat-sahabat yang lain.

\section{Para Mufassir Al-Quran Dalam Sejarah Islam}

\section{Ibnu Katsir dan Corak Penafsirannya}

a) Biografi

Ibnu Katsir adalah pengarang tafsir Ibnu Kasir yang bernama I'mad al-Din Isma'il ibn 'Umar ibn Kasir al-Quraisyqi. Ia biasa dipanggil dengan panggilan Abu al-Fida'. Beliau lahir di Basrah tahun 700 H/1300 M. Di bidang hadits, Ibn katsir banyak belajar dari ulama-ulama Hijaz. Ia medapatkan ijazah dari al-Wani. Ia juga dididik oleh pakar hadits terkenal di Suriah yakni Jamal ad-Din al-Mizzi (w, 742 H/ $1342 \mathrm{M}$ ), yang kemudian dijadikan mertuanya sendiri.

\section{b) Metode Penafsiran}

Kitab ini dapat dikaegorikan sebagai salah satu kitab tafsir dengan corak dan orientasi (al-laun wa al-ittijah) tafsir bi al-ma'sur atau tafsir bi al-riwayah. Ini terbukti karena beliau sangat dominan dalam tafsirannya memakai riwayah atau hadits, dan pendapat sahabat dan tabi'in. Dapat dikatakan bahwa dalam tafsir ini yang paling dominan ialah pendekatan normatif historis yang berbasis

\footnotetext{
${ }^{16} \mathrm{Ibid}, 373$
} 
utama kepada hadits atau riwayah. Namun Ibnu Kasir pun terkadang menggunakan rasio atau penalaran ketika menafsirkan ayat. Ia adalah Ismail bin Amr Al-Quraisyi bin Katsir Al-Bashri Ad-Dimasyqi Imaduddin Abu Al-Fida AlHfizh Al-Muhaddits Asy-Syafi'i. Dilahirkan pada 705 H. dan wafat pada 774 H., sesudah menempuh kehidupan panjang yang sarat dengan keilmuan. Ibnu Katsir seorang pakar fikih yang mumpuni, ahli hadits yang cerdas, sejarawan ulung dan mufassir unggulan. Menurut Ibnu Hajar, Ibnu Katsir seorang ahli hadits yang fakih. Karya-karyanya tersebar luas di berbagai negeri semasa hidupnya dan bermanfaat bagi orang banyak setelah wafatnya. ${ }^{17}$

\section{c) Karya-Karyanya}

Di antara karya tulisannya :

- Al-Bidayah wa An-Nihayah, dalam bidang sejarah. Kitab ini termasuk referensi terpenting bagi sejarawan.

- Al-Kawakib Ad-Darari, dalam bidang sejarah, semacam ringkasan dari AlBidayah wa An-Nihayah.

- Tafsir Al-Qur'an

- Al-Ijtihad wa Thalab Al-Jihad.

- Jami' Al-Masanid;

- As-Sunnah Al-Hadi li Aqwami Sunan.

- AlWadih An-Nafis fi Manaqib Al-Imam Muhammad bin Idris.

\section{d) Corak Tafsirnya}

Dalam hal ini, Rasyid Ridha berkomentar, "Tafsir ini merupakan tafsir paling masyhur yang memberikan perhatian besar terhadap riwayat-riwayat dari para mufassir salaf, menjelaskan makna-makna ayat dan hukumnya, menjauhi pembahasan masalah i'rab dan cabang-cabang balaghah yang pada umumnya dibicarakan secara panjang lebar oleh kebanyakan mufassir, menghindar dari pembicaraan yang melebar pada ilmu-ilmu lain yang tidak diperlukan dalam memahami Al-Qur'an secara umum atau hokum dan nasehat-nasehatnya secara khusus." Di antara cirri khas tafsirnya ialah perhatiannya yang besar kepada masalah tafsir Al-Qur'an bi Al-Qur'an (menafsirkan ayat dengan ayat). Sepanjang pengetahuan kami, tafsir ini merupakan tafsir yang paling banyak memuat atau memaparkan ayat-ayat yang bersesuaian maknanya, kemudian diikuti dengan penafsiran ayat dengan hadits-hadits marfu' yang relevan dengan ayat yang sedang ditafsirkan, menjelakan apa yang menjadi dalil dari ayat tersebut. Selanjutnya diikuti dengan atsar para sahabat, pendapattabi'in dan

${ }^{17}$ Syaikh Manna Al-Qattan, Pengantar Studi Ilmu Qur'an, (Jakarta: Pustaka Al-Kautsar, 
ulama salaf sesudahnya. ${ }^{18}$ Keistimewaan lain dari tafsir ini, daya kritisnya yang tinggi terhadap cerita-cerita Israiliyat yang banyak tersebar dalam kitab-kitab tafsir bil-ma'tsur, baik secara global maupun mendetail. Namun alangkah akan lebih baik lagi andaikata ia menyelidikinya secara tuntas, atau bahkan tidak memuatnya sama sekali jika tidak untuk keperluan filterisasi dan penelitian.

\section{Ibnu Abbas Corak Penafsirannya}

\section{a) Biografi}

Ibnu Abbas adalah Abdullah bin Abbas bin Abdul Muthalib bin Hasyim bin Abdi Manaf Al-Quraisyi Al-Hasyimi, putra paman Rasulullah Shallallahu 'Alaihi wa Sallam, Ibunya bernama Ummu Al-Fadhl Lubanah binti Al-Harits AlHilaliah. Ia dilahirkan ketika Bani Hasyim berada di Syi'ib, tiga atau lima tahun sebelum hijrah, namun pendapat pertama lebih kuat. ${ }^{19}$ Abdullah bin Abbas menunaikan ibadah harji pada tahun Utsman bin Affan terbunuh, atas perintah Utsman. Ketika terjadi perang shiffin, ia berada di Al-Maisarah, kemudian diangkat menjadi gubernur Bashrah dan selanjutnya menetap di sana sampai Ali terbunuh. Kemudian ia mengangkat Abdullah bin Al-Harits, sebagai penggantinya, menjadi gubernur Bashrah, sedang ia sendiri pulang ke Hijaz. Ia wafat di Thaif pada $65 \mathrm{H}$. pendapat yang dipandang shahih oleh jumhur ulama. Al-Waqidi menerangkan, tidak ada selisih pendapat di antara para imam bahwa Ibnu Abbas dilahirkan di Syi'ib ketika kaum Quraisy memboikot Bani Hasyim, dan ketika Nabi wafat ia baru berusia tiga belas tahun.

\section{b) Posisi Keilmuannya}

Ibnu Abbas dikenal dengan gelar Turjuman Al-Qur'an (penafsir AlQur'an). Habrul Ummah (guru umat), dan Ra'isul mufassirin (pemimpin para mufassir). Al-Baihaqi dalam Ad-Dala'il meriwayatkan dari Ibnu Mas'ud, "Penafsir Al-Qur'an terbaik adalah Ibnu Abbas". "Abu Nu'aim meriwayatkan keterangan dari Mujahid, adalah Ibnu Abba Dijuluki dengan Al-Bahr (lautan) karena banyak dan luas ilmunya. Ibnu Sa'ad meriwayatkan pula dengan sanad yang shahih dari Yahya bin Sa'id Al-Anshari, "Ketika Zaid bin Tsabit wafat, Abu Hurairah berkata, "Orang paling pandai umat ini telah wafat dan semoga Allah menjadikan Ibnu Abbas sebagai penggantinya."

Dalam usia muda, Ibnu Abbas telah mendapat tempat yang istimewa di kalangan para senior sahabat mengingat ilmu dan ketajaman pemahamannya, sebagai wujud dari do'a Rasulillah untuknya. Dalam sebuah riwayat dari Ibnu

\footnotetext{
${ }^{18}$ Syaikh Manna Al-Qattan...,479

${ }^{19}$ Ibid, 473.
} 
Abbas sendiri dijelaskan, "Nabi pernah merangkulnya dan berdo'a, Ya Allah, ajarkanlah kepadanya hikmah." Dalam Mu'jam Al-Baghawi dan lainnya, dari Umar bin Al-Khatthab, "Beliau menekati Ibnu Abbas dan berkata, sungguh saya telah melihat Rasulullah mendoakanmu, lalu membelai kepalamu, meludahi mulutmu dan berdoa, 'Ya Allah, berilah ia pemahaman yang hebat dalam urusan agama dan ajarkanlah kepadanya takwil.",

Bukhari, dari jalur sanah Sa'id bin Jubair, meriwayatkan dari Ibnu Abbas, ia menceritakan, "Umar mengikutsertakan saya kedalam kelompok para tokoh senior perang Badar. Nampaknya sebagian mereka merasa kurang suka lalu berkata, 'Kenapa anak ini diikutsertakan ke dalam kelompok kami, padahal kami pun mempunyai anak-anak yang sepadan dengannya?' Umar menjawab, 'Ia memang seperti yang kamu ketahui.'Pada suatu hari Umar memanggil mereka dan mengajak saya bergabung dengan mereka. Saya yakin, Umar memanggilku itu semata-mata hanya untuk "memamerkan" saya kepada mereka. Ia berkata, 'Bagaimana pendapat tuan-tuan mengenai firman Allah, "apabila pertolongan dan kemenangan Allah telah tiba.” (An-Nasr:1). Sebagian mereka menjawab, 'Kita diperintaj untuk memuji Allah dan memohon ampunan kepada-Nya ketika Dia memberi kita pertolongan dan kemenangan.' Sedang yang lain diam, tidak berkata apa pun. Lalu Umar berkata kepadaku,' Begitukah pendapatmu, hai Ibnu Abbas?' 'Tidak,' jawabku. 'Lalu bagaimana menurutmu?' tanyanya lebih lanjut. Saya pun menjawab, 'Ayat itu adalah sebagai pertanda tentang ajal Rasulullah Shallallahu alaihi wa sallam, yang Allah informasikan kepadanya, "Apabila pertolongan dan kemenangan dari Allah telah dating," -dan itu sebagai pertanda ajalmu, wahai Muhammad- "Maka bertasbihlah dengan memuji Tuhanmu dan mohon ampunlah kepada-Nya. Sesungguhnya Ia Maha penerima taubat." Umar pun berkata, "Aku tidak mengetahui maksud ayat itu kecuali apa yang kamu katakana."

\section{c) Corak Tafsir Ibnu Abbas}

Riwayat dari Ibnu Abbas mengenai tafsir tidak terhitung banyaknya, dan apa yang dinukil darinya itu telah dihimpun dalam sebuah kitab tafsir ringkas yang kurang sistematis tajuknya Tafsir Ibnu Abbas. Di dalamnya terdapat macam-macam riwayat dan sanad. Tetapi sanad yang terbaik adalah melalui jalur Ali bin Thalhah Al-Hasyim, dari Ibnu Abbas. Sanah ini menjadi pedoman Bukhari dalam kitab shahihnya. Sedang sanah yang cukup baik, dari jalur Qais bin Muslim Al-Kufi, dari 'Atha' bin As-Sa'ib. ${ }^{20}$

${ }^{20}$ Syaikh Manna Al-Qattan, Pengantar Studi Ilmu Qur'an, (Jakarta: Pustaka Al-Kautsar, 
Di dalam kitab-kitab tafsir besar yang disandarkan kepada Ibnu Abbas terdapat kerancuan sanad. Sanad paling rancu dan lemah, sanad melalui jalur AlKalbi dari Abu Shalih. Al-Kalbi sendiri adalah Abu An-Nashr Muhammad bin As-Sa'ib (wafat. 146 H.) Jika sanad ini digabungkan dengan riwayat Muhammad bin Marwan As-Suddi As-Shaghir, maka akan menjadi sebagai silsilah al-kadzib (mata rantai kebohongan). Demikian juga sanad Muqatil bin Sualiman bin Bisyr Al-Azdi. Hanya saja Al-Kalbi lebih baik dari padanya. Karena Muqatil terikat dengan berbagai madzhab atau paham yang kurang baik.

Sementara itu sanad Adh-Dhahhak bin Muzahim Al-Kufi dari Ibnu Abbas munqathi', (terputus). Karena Adh-Dhahhak tidak berjumpa langsung dengan Ibnu Abbas. Apabila digabungkan kepadanya riwayat Bisyr bin Imarah, maka riwayat Juwaibir dari Adh-Dhahhak, maka riwayat ini tetap lemah karena Bisyr memang lemah. Dan jika sanad itu melalui riwayat Juwaibir dari Adh-Dhahhak, maka riwayat tersebut sangat lemah karena Juwaibir sangat lemah dan riwayatnya ditinggalkan ulama. Sanad melalui Al-'Aufi, dan seterusnya dari Ibnu Abbas, banyak dipergunakan oleh Ibnu Jarir dan Ibnu Abi Hatim, padahal Al'Aufi itu seorang yang lemah meskipun lemahnya tidak keterlaluan dan terkadang dinilai hasan oleh At-Tirmidzi. Dengan penjelasan tersebut dapatlah kiranya pembaca menyelidiki jalur periwayatan tafsir Ibnu Abbas, dan mengetahui mana jalur yang cukup baik dan diterima, serta mana pula jalur yang lemah atau ditinggalkan, sebab tidak setiap yang diriwayatkan dari Ibnu Abbas itu shahih dab pasti. Masalah ini telah kami kemukakan lebih rinci pada bagian terdahulu ketika membicarakan tentang tafsirnya.

\section{At-Thobari dan Corak Penafsirannya}

\section{a) Biografi}

Nama lengkapnya Muhammad bin Jair bin Yazid bin Khalid bin Katsir Abu Ja'far Ath_Thabari, berasal dari Amil, lahir dan wafat di Baghdad. Dilahirkan pada $224 \mathrm{H}$. dan wafat pada $310 \mathrm{H}$. Ia seorang ulama yang sulit dicari bandingnya, banyak meriwayatkan hadits, luas pengetahuannya dalam bidang penukilan, penarjihan riwayat-riwayat, sejarah tokoh dan umat masa lalu. ${ }^{21}$

\section{b) Karya-Karyanya}

Ath-Thabari menulis kitab cukup banyak, antara lain :

- Jami' Al-Bayan fi Tafsir Al-Qur'an

- Tarikh Al-Amam wa Al-Muluk wa Akhbaruhum

- Al-Adab Al-Hamidah wa Akhlaq An-Nafisah

\footnotetext{
${ }^{21} \mathrm{Ibid}, 477$.
} 
- Tarikh Ar-Rijal

- Ikhtilaf Al-Fuqaha'

- Tahdzib Al-Atsar

- Kitab Basth fi Al-Fiqh

- Al-Jami' fi Al-Qira'at

- Kitab Tabshirfi Ushul

c) Corak Tafsirnya

Kitabnya tentang tafsir, Jami' Al-Bayan fi Tafsir Al-Qur'an, merupakan tafsir paling besar dan utama, menjadi rujukan penting bagi para mufassir bilma'tsur. Ibnu Jarir memaparkan tafsir dengan menyandarkannya kepada sahabat, tabi'in dan tabi'ut tabi'in. Ia juga mengemukakan berbagai pendapat bahwa belum pernah sebuah kitab tafsir pun yang ditulis sepertinya. An-Nawawi dalam Tahdzib-nya mengemukakan, nada yang sama dalam menilai kitab tafsir ini. Ibnu Jarir mempunyai keistimewaan tersendiri berupaistinbath hokum yang hebat, pemberian isyarat terhadap kata-kata yang samar i'rabnya. Dengan itulah, antara lain tafsir tersebut berada di atas tafsir-tafsir lainnya. Sehingga Ibnu Katsir pun banyak menukil darinya.

\section{Asy-Syaukani dan Corak Tafsirnya}

\section{a) Biografi}

Asy-Syaukani memiliki anama lengkap Al-Qadhi Muhammad bin Ali bin Abdullah Asy-Syaukani Ash-Shan'ani. Dia seorang imam mujtahid, pembela sunnah dan penghancur bid'ah. Dilahirkan pada 1173 H. di kampung Syaukan dan dibesarkan di Shan'a. belajar Al-Qur'an dengan serius. Menurut ilmu dengan tekun dari ulama-ulama besar, banyak menghafal kitab tentang nahwu, sharaf dan balaqhah. Juga menguasai ilmu ushul, metodologi penelitian, dan ilmu berdebat, sehingga ia menjadi seorang imam yang mumpuni. Sepanjang hayatnya, ia senantiasa bergelut dengan masalah keilmuan, baik dengan cara membaca maupun dengan mengajar. Demikianlah hingga ajal menjemputnya pada $1250 \mathrm{H}$.

\section{b) Madzhab dan Akidahnya}

Asy-Syaukani mempelajari glfikih dari madzahab Imam Zaid, sampai menjadi tokoh utamanya yang selalu menulis karya, dan memberi fatwa. Lalu belajar hadits hingga menjadi seorang ulama besar pada masanya. Namun pada akhirnya ia menjadi pembela sunnah dan banyak mengalahkan lawan-lawan 
polemiknya. Menurutnya taklid haram. Buku berkenaan yang ia tulis adalah AlQaul Al-Mufid fi Adillah Al-ijtihad wa At-Taqlid. ${ }^{22}$

\section{c) Karya-Karyanya}

Ia mempunyai sejumlah karya yang bagus dalam berbagai disiplin ilmu. Di antaranya :

- $\quad$ Fath Al-Qadir (tentang tasfir)

- Nail Al-Authar (sebuah syarah atas kitab Al-Muntaqa Al-Akhbar, karya Majid Ibnu Taimiyah kakek daripada Syaikhul Islam Ibnu Taimiyah. Sebuah kitab terbaik yang ditulis dengan pendekatan fikih).

- Irsyad Al-Fuhul (tentang Ushul Fikih)

- Al-Fath Ar-Rabbani (kumpulan fatwanya)

d) Corak Tafsirnya

Adalah Fath Al-Qadir, satu karya tafsir Asy-Syaukani yang menggabungkan antara riwayat, penalaran dan pengambilan hokum atas ayatayat yang ditafsirkannya. Dalam tafsir ini, Beliau banyak merujuk pada para mufassir seperti An-Nahhas, Ibnu 'Athiyah, dan Al-Qurthubi. Kini tafsirnya ini banyak beredal luas di berbagai dunia Islam. Semoga Allah senantiasa melimpahkan shalawat dan salam kepada Rasul kita Muhammad, keluarga dan sahabatnya. Amin.

\section{Penutup}

Ilmu tafsir merupakan ilmu yang sangat penting dalam memahami Al-Qur'an. Tanpa mengetahui ilmu tafsir kita tidak akan mampu untuk memahami Al-Qur'an secara benar. Untuk menjelaskan Al-Qur'an diperlukan orang-orang yang mempunyai otoritas keilmuan khusus dibidang Al-Qur'an. Rasulullah SAW telah mengajarkan kepada kita semua tentang bagaimana cara memahami Al-Qur'an. Cara yang diajarkan Oleh Rasulullah SAW adalah dengan mengembalikan pemahaman AlQur'an kepada pemahaman Rasulullah SAW dan para sahabat. Rasulullah SAW merupakan utusan Allah yang mana Al-Qur'an langsung turun kepadanya dan yang menjadi guru Rasulullah SAW adalah malaikat Jibril. Sedangkan para sahabat merupakan Murid Rasulullah SAW. Mereka para sahabat telah mendapatkan predikat dari Allah SWT dengan predikat orang-orang yang Allah Ridhoi. Selepas Rsululullah SAW dan para sahabat penafsiran Al-Qur'an dilakukan oleh para ulama yang mempunyai kewenangan dengan keilmuan yang khusus dibidang Al-Qur'an seperti penafsiran yang dilakukan oleh Ibn Katsir, Ibnu Abbas, At-Thobari As-Syaukani dll. 2013), 483 .

${ }^{22}$ Syaikh Manna Al-Qattan, Pengantar Studi Ilmu Qur'an, (Jakarta: Pustaka Al-Kautsar, 
Mereka itulah yang mempunyai kewenangan untuk menafsirkan Al-Qur'an sehingga tafsiran mereka menjadi rujukan untuk semua umat di seluruh dunia.

\section{DAFTAR PUSTAKA}

Ahmad, Syadali, Ahmad Rafi'i. Ulumul Quran .Bandung : CV. Pustaka Setia, 1997.

Ali Hasan Al-Aridl. Sejarah dan Metodologi Tafsir (terj.).Jakarta: Raja Grafindo Persada, 1994.

Abdul Hayy Al-Farmawi. Metode Tafsir Maudhu'i dan Penerapannya. Bandung: Pustaka Setia, 2002.

Syaekh Muhammad Shalih Al-Utsaimin, Sejarah Pengantar Ilmu Tafsir Ibnu Taimiyah, Penerj. Sholihin. Jakarta: Pustaka Al-Kautsar, 2014.

M. Hasbi Ash Shiddieqy. Sedjarah dan Pengantar Ilmu al-Quran/Tafsir. (Jakarta: Bulan Bintang, 1972.

Muhammad Baqir Hakim, Ulumul Qur'an. Jakarta: Al-Huda, 2011.

Mushaf Al-Qur'anul Karim Syaikh Manna Al-Qattan, Pengantar Studi Ilmu Qur'an, Jakarta: Pustaka Al-Kautsar, 2013.

Syaekh Muhammad Shalih Al-Utsaimin, Sejarah Pengantar Ilmu Tafsir Ibnu Taimiyah, Penerj. Sholihin. Jakarta: Pustaka Al-Kautsar, 2014. 